\title{
Ageing and Resultant Changing Gender Roles of Farmers' Involvement in Cocoa Production in Ekiti State, Nigeria
}

\author{
Ayodele Omowunmi Veronica
}

Department of Agricultural Extension and Communication Technology, Federal University of Technology, Akure, Nigeria

\section{Email address:}

ayodeleomowunmi2002@yahoo.com,ovayodele@futa.edu.ng

\section{To cite this article:}

Ayodele Omowunmi Veronica. Ageing and Resultant Changing Gender Roles of Farmers' Involvement in Cocoa Production in Ekiti State, Nigeria. Agriculture, Forestry and Fisheries. Vol. 9, No. 3, 2020, pp. 39-44. doi: 10.11648/j.aff.20200903.11

Received: October 24, 2019; Accepted: November 21, 2019; Published: May 28, 2020

\begin{abstract}
Ageing is inevitable and it will undoubtedly affect farmers' involvement in agricultural activities. The study examined the changing patterns of involvement of male and female in cocoa production activities as they age in Ekiti State, Nigeria. Multi-stage sampling technique was used to select 90 males and 50 females cocoa farmers who were below 50 years and above 50 years for the research and were interviewed with structured questionnaire. Descriptive and inferential statistics were used to analyze the data. Results showed that the mean age for males was 54 years and 52 years for females. Involvement in organisation decision making was higher for male $(48.8 \%)$ than for female $(29.1 \%)$. The result of the four point Likert rating scale on changing pattern of involvement with respect to age showed that both male and female were always involved in all cocoa production activities when they were less than 50 years old. "Always involved" had the least of 55.8\% for choosing of farm site and highest of $81.4 \%$ for marketing, hiring of labourers and sourcing for fund. However, females had low level of involvement for all the activities when they were above 50 years, while the males had high level of involvement for only two activities; marketing and sourcing for fund when above 50 years. The t-test result revealed a difference in the level of involvement of respondents when below 50 years and above 50 years with mean of 2.8 and 1.68 respectively, ( $t=4.68$, $\mathrm{p} \leq$ 0.05). Conclusively, age affected the involvement of farmers in most cocoa production activities. As a result, recruitment of younger farmers in cocoa production was recommended.
\end{abstract}

Keywords: Age, Involvement, Gender, Farmers, and Cocoa

\section{Introduction}

\subsection{Background of the Study}

The significance of agriculture to the development of agrarian economies cannot be disputed. It has continued to play principal role in the provision of food, raw materials for the industries, employment and foreign exchange generation. Agriculture contributed $21.91 \%$ to Nigeria's GDP in the first quarter of 2019 [1]. A prominent crop in the agricultural sector in West Africa is cocoa. Cocoa (Theobroma cacao) is an important perennial crop and a major foreign exchange earner for some counties in Africa. The world produced 4.744 million metric tons of dried cocoa beans in 2017 and $76 \%$ of the world production comes from Africa with about $7 \%$ of the continent exports from Nigeria, making it the $6^{\text {th }}$ in the world [2]. World Cocoa production figures in 2018/2019 reveals that African countries were the five leading producing countries in the world with 2150, 900, 298, 250, 245 (in 1000 metric tons) by Cote d'Ivoire, Ghana, Ecuador, Cameroon and Nigeria respectively [3]. Cocoa is a strategic asset to Nigerian government and it plays a critical role in sustaining Nigeria's workforce [4]. It provides a means of livelihood for more than five million people [5].

\subsection{Theoretical Review}

There has been a decline in cocoa production in Nigeria over the years. The fall in percentage share of cocoa output in Nigeria may be attributed to the negligence of the agricultural sector as a result of the oil boom, abolition of the Nigerian Cocoa marketing Board (NCMB), old age of cocoa farms and farmers, incidence of pests and diseases, lack of credit facilities to cocoa farmers and climate variability [6]. Furthermore, a major problem with agricultural development in Nigeria is the ageing farm population without sustainable replacement confirming that the average age of the farmer in 
Nigeria is 65years [7]. In most societies including Nigeria, people who are 65 years and above are already retired from active work or service, but this is not so in agriculture. It is not surprising to see farmers in their 70 s still farming fulltime [8]. Unlike the rest of the population, farmers tend to remain in farming beyond the normal retirement age. In Nigeria, young people do not want to take on farming as a profession mainly because of its inherent association with poverty [7]. Other evidences suggest an ageing farming population in Nigeria, with an average age of 47 years and life expectancy at 47-50 years in 2010 [1,9]. Ageing is the accumulation of changes in an organism or object over time [10]. Ageing in humans refers to a multidimensional process of physical, psychological, and social change. Some dimensions of ageing grow and expand over time, while others decline. Reaction time, for example, may slow with age, while knowledge of world events and wisdom may expand. Ageing is an important part of all human societies reflecting the biological changes that occur, but also reflecting cultural and societal conventions.

\subsection{Statement of Problem}

The age of farmers imposes great limitation on farmers' activities [11], as it has been noted that agility, strength and proneness to change diminishes. This invariably affects their activities whether domestic or other productive roles. Moreso, physiological and biological differences between the sexes is likely to influence the responses of their anatomy and body systems based on what they have passed through in their roles as men and women. Ageing poses multifaceted challenges to individuals, and also has implications for both male and females in varying degrees. Understanding the demographics of an agricultural population is one of the first and most important steps in addressing inherent issues in agriculture. This scenario therefore calls for an inquiry into how changes in the age of the cocoa farmers who contribute largely to the nation's GDP affects their involvement in cocoa production vis- a -vis their gender biases. Providing a gender disaggregate data will also help policy makers and relevant stake holders make more informed decisions on how to address the ageing population in cocoa industry. This is also important because women and men are likely to differ also in their capacity, authority or availability to participate in livelihoods interventions, so attention must be given to overcoming such barriers.

\subsection{Objective of the Study}

\subsubsection{General Objective}

The overall objective of this study was to examine whether or not the involvement of males and females in cocoa production activities is being affected by age.

\subsubsection{Specific Objectives}

(1) It ascertained the socio-economic characteristics of the cocoa farmers in the study area.

(2) It examined the changing patterns of involvement of men and women in cocoa production activities as they age.

\section{Methodology}

\subsection{The Study Area}

The study was conducted in Ekiti State, Nigeria. It lies between latitude $7^{0} 15^{1}$ and $8^{0} 7^{1}$ North of the equator and longitude $4^{0} 47^{1}$ and $5^{0} 45^{1}$ East of the Greenwich Meridian. It has a mean annual rainfall of about $1400 \mathrm{~mm}$ and a mean annual temperature of about $27^{\circ} \mathrm{C}$. The State is bounded to the North by Kwara and Kogi States, to the South and East by Ondo State and to the West by Osun State. Ekiti state is a major producer of both tree and food crops. Multi-stage sampling technique was used to for the research.

\subsection{Sampling Procedure and Sampling Size}

Three Local Government Areas (LGAs) with a minimum of 1,000 metric tonnes of cocoa output per annum were purposely selected. They were Ise-Orun (highest), Gbonyin and Ekiti South West. Three towns were randomly selected from the highest producing LGA while two towns were selected from the remaining two LGAs making a total of seven towns/communities. 70 males and 50 females cocoa farmers who were below 50 years and equal/above 50 years for the research and were interviewed with the structured questionnaire. However, only 117 copies of questionnaire were suitable for the study. Frequencies, means, percentages and t-test were used to analyze the data.

\subsection{Operationalization of Variables}

Respondents' Involvement in cocoa production activities was assessed on twenty various activities when they were at different age categories; $<50$ years, and $\geq 50$ years using a four point Likert scale. Thus: Always Involved (AI) -4 , Most Times Involved (MTI) - 3, At Times Involved (ATI) 2 , Not Involved -1 (NI). Data was further categorized by adding the values of the Likert-type scale to obtain 10 , which was later divided by 4 , to obtain a mean score of 2.5 . Then, any activity with a mean score that was equal or higher than 2.5 was categorized as high involvement, while a mean score lower than 2.5 was categorized as low involvement.

\section{Results and Discussion}

\subsection{Socio-economic Characteristics of the Respondents}

As shown on Table 1, males were more involved in cocoa production in the study area. Out of the 117 respondents, 86 were male. The mean age for male respondents was 54 and 52 for the females which implies that majority of the respondents were old aged. This is in tandem with $[12,13]$ that mean age for cocoa farmers was 53 . The fact that cocoa farmers are old aged has implication on agricultural productivity. The old age of farmers is a major concern in the agricultural sector [7]. There was a high illiteracy level among the respondents with $41.9 \%$ male and $45.2 \%$ female having no formal education. Only $13.9 \%$ male and $6.5 \%$ female had post-secondary education. The rest respondents 
had some form of education varying from adult through secondary education. The low level of education in the study area has implication on promotion of the transfer, acquisition and adoption of appropriate and sustainable technologies. The study revealed that male respondents had more farming experience than the female. The mean for male (23 years) doubled that of female (11 years). This implication of this much difference on the farmers' involvement in cocoa production is that males are often involved in cocoa production. [14, 15] affirm that mean year for farming experience for cocoa farmers was 17 years. The mean farm size was 2.0 ha, implying that cocoa cultivation in the study area is dominated by small-scale farmers with average cocoa output of 8 bags for male and 7 bags for female. The difference in the outputs of male and female might be is attributed to differences in farm management practices adopted by both genders considering the fact that about $80 \%$ of male managed cocoa farm by self while only $19.4 \%$ of female did. The most prominent mode of farm acquisition was through inheritance for both genders as 50.0\% male inherited their cocoa farm while $77.5 \%$ female did. Only few male $(27.9 \%)$ and female $(12.8 \%)$ established their cocoa farms themselves. The implication of this is old age for cocoa. The study, further shows that $97.7 \%$ of the male respondents and the female respondents belonged to one social group or the other. This implies females are more prone to joining social organization than male. The involvement of majority of the respondents in one group or the other further implies better adoption of innovation as communication to groups aids better diffusion of information. [16], also posited that farmers' involvement in social organisations put them in a better position to have access to assistance from government in from of loan and other inputs.

Table 1. Distribution of Respondents according to socio-economic characteristics.

\begin{tabular}{|c|c|c|c|c|}
\hline Characteristics & Male $\%(n=68)$ & Female\% $(n=49)$ & All Respondents \% $(n=117)$ & Mean \\
\hline \multicolumn{5}{|c|}{ Age of Farmers (years) } \\
\hline$\leq 40$ & 29.1 & 22.5 & 27.4 & \\
\hline $41-50$ & 9.3 & 9.6 & 9.4 & M-54 \\
\hline $51-60$ & 33.7 & 45.4 & 36.8 & F-52 \\
\hline $61-70$ & 12.8 & 22.5 & 15.4 & Both - 53 \\
\hline$>70$ & 15.1 & 0.0 & 11.0 & \\
\hline \multicolumn{5}{|l|}{ Educational Status } \\
\hline Adult & 5.8 & 12.9 & 7.7 & \\
\hline Primary & 15.1 & 19.4 & 16.2 & \\
\hline Secondary & 23.3 & 16.1 & 21.4 & \\
\hline Post-Secondary & 13.9 & 6.5 & 12 & \\
\hline \multicolumn{5}{|l|}{ Farming Experience } \\
\hline$\leq 20$ & 55.8 & 96.8 & 66.7 & M-23 \\
\hline $21-40$ & 25.6 & 3.2 & 18.9 & F-11 \\
\hline \multicolumn{5}{|l|}{ Farm Size (ha) } \\
\hline$<2.5$ & 50.0 & 96.8 & 62.4 & M-2.5 \\
\hline $2.5-5$ & 37.2 & 3.2 & 28.2 & $\mathrm{~F}-1.5$ \\
\hline$>5$ & 12.8 & 0 & 9.4 & Both -2.0 \\
\hline \multicolumn{5}{|c|}{ Output in Bags (65kg) } \\
\hline$<5$ & 11.6 & 9.7 & 11.1 & $M-8$ \\
\hline$>5-9.9$ & 53.5 & 77.4 & 59.8 & $\mathrm{~F}-7$ \\
\hline$>10-14.9$ & 24.4 & 9.7 & 20.5 & Both -7.5 \\
\hline$\geq 15$ & 10.5 & 3.2 & 8.6 & \\
\hline \multicolumn{5}{|c|}{ Farm Acquisition mode } \\
\hline Inherited & 50.0 & 77.5 & 57.3 & \\
\hline Bought & 12.8 & 9.7 & 12.0 & \\
\hline Leased & 9.3 & 0 & 6.8 & \\
\hline Established by self & 27.9 & 12.8 & 23.9 & \\
\hline \multicolumn{5}{|c|}{ Organisation Membership } \\
\hline Yes & 97.7 & 100.0 & 98.3 & \\
\hline
\end{tabular}

Source: Field survey, 2015.

\subsection{Management System Adopted}

Figure 1 shows that, majority $(79.1 \%)$ of the male respondents adopted self- management system, while few $(19.4 \%)$ of the female did. Very few of the respondents managed their farm by either leasing to another farmer or giving to another relative to manage. Share cropping was mostly $(45.2 \%)$ adopted by the female respondents while only $7 \%$ of males used the system. This implies that women made use of sharecroppers more than men in cocoa production activities and this will lead to a reduction in the profit accrued to female cocoa farmers since the profit will have to be shared between the parties involved. A distinct characteristic of cocoa farms in Nigeria is the high percentage under the sharecropping arrangements [17]. 


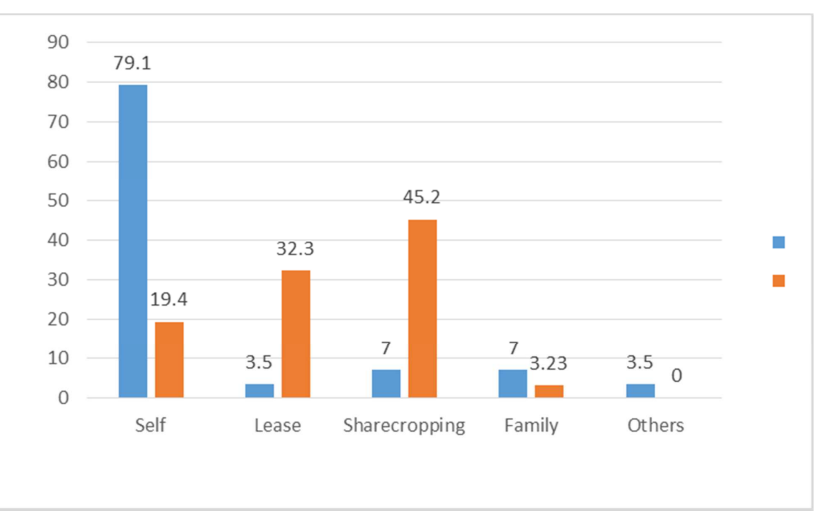

Source: Field survey, 2015.

Figure 1. Management System Adopted.

\subsection{Changing Pattern of Involvement of Male and Female in Cocoa Production Activities with Respect to Age}

Tables 2 and 3 show the changing pattern of male and female involvement in cocoa production activities with respect to age. The result showed that the males had high level of involvement in all the cocoa production activities when they were $<50$ years old. Marketing of produce had the highest level of involvement $(\overline{\mathrm{x}}=3.42)$, while bush clearing and land preparations had was the least $(\bar{x}=2.79)$. The minimum percentage for "Always Involved" for all the activities was $55.8 \%$, for choosing location for farm site and the maximum was $81.4 \%$ for marketing, sourcing for fund and hiring labourers. On the contrary, only sourcing fund for farm operations and marketing had high level of involvement $(\bar{x}=2.50)$ when the males were $\geq 50$ years. Male's involvement in cocoa production activities when $\geq 50$ years for 'Always Involved' was never above $54.7 \%$ for all the activities. Choosing location for farm site had the highest percentage $(54.7 \%)$ of respondents when $\geq 50$ years. "Not at all Involved" was seen to have the highest percentages for all the activities when males $\geq 50$ years. This result implies that male involvement in coca production activities decreased with age.

The result further shows that the females did not have high level of involvement in all the cocoa production activities when compared to the male counterparts. The activities with high level of involvement were; scooping of cocoa seeds from pods, fermentation and checking of cocoa beans, bagging/storage of dried cocoa beans, sun-drying and removal of bad cocoa beans, hiring labourers and determining wages, transportation of cocoa beans within farm, marketing of cocoa produce, sourcing fund for farm operations, sourcing for farm inputs, raising cocoa seedlings nursery, planting of cocoa seedlings, spraying against pests \& diseases, harvesting of ripped cocoa pods, and breaking of cocoa pods with mean score of 3.6, 3.6, 3.5, 3.4, 3.3, 2.9, 2.8, $2.7,2.7,2.6,2.6,2.5,2.5$ and 2.5 respectively. The activities with the least level of involvement for females when they were below 50 years were weeding and pruning of cocoa farm and bush clearing and land preparation $(\overline{\mathrm{x}}=1.9)$. This is because these activities are very labourious in nature. In line with [18], women involvement in such activities are lower compared to men because of the drudgery nature. The study also shows that females were consistently "Always Involved" in all the activities except for the activities associated with land preparations when $<50$ years. A study carried out by [19] showed the contributions of men to decision making at pre-harvest stage of cocoa production activities were exceedingly high. However, there was no activity where the females had high level of involvement when they were $\geq 50$ years. Bagging and storage of dried cocoa beans had the least level of involvement at this age $(\overline{\mathrm{x}}=1.9)$. This showed that female involvement in cocoa production activities reduced drastically with age. The study further shows that, "Never Involved" had the highest percentage for choosing land for farm site, $18.6 \%$ for male and $54.7 \%$ for female. This is so because majority of the respondents inherited their cocoa farms, thus they were never involved in choosing farm site location.

On the overall, the results show that both male and female were involved in cocoa production activities, however, there was a decline in level of involvement for both male and female with increase in age. This implies that age affects the level of involvement of farmers in cocoa production activities. With decreased in the level of involvement, decrease in cocoa output is inevitable. In Africa, both cocoa farmers and farms are aged and this results to low cocoa yield $[20,21]$.

Table 2. Changing Pattern of Male Involvement in Cocoa Production as affected by Age.

\begin{tabular}{|c|c|c|c|c|c|c|c|c|c|c|c|c|}
\hline \multirow{2}{*}{ Cocoa Production Activities } & \multicolumn{7}{|c|}{ Male $<50$ Years $(\%), N=68$} & \multicolumn{5}{|c|}{ Male $>50$ Years $(\%), N=68$} \\
\hline & AI & MTI & ATI & NI & MS & SD & AI & MTI & ATI & NI & MS & SD \\
\hline Choosing location for farm site & 55.8 & 22.1 & 3.5 & 18.6 & $2.80^{*}$ & 1.6 & 36.0 & 7.0 & 2.3 & 54.7 & 1.64 & 1.9 \\
\hline Bush clearing and land preparation & 59.3 & 12.8 & 12.8 & 15.1 & $2.79 *$ & 1.6 & 17.4 & 18.6 & 10.5 & 53.5 & 1.24 & 1.6 \\
\hline Securing planting materials & 74.4 & 8.1 & 4.7 & 12.8 & $3.12 *$ & 1.5 & 39.5 & 18.6 & 3.5 & 38.4 & 2.15 & 1.8 \\
\hline Raising cocoa seedlings nursery & 61.6 & 16.3 & 7.0 & 15.1 & $2.93 *$ & 1.5 & 32.6 & 22.1 & 7.0 & 38.4 & 1.98 & 1.8 \\
\hline Planting of cocoa seedlings & 59.3 & 18.6 & 9.3 & 12.8 & $2.91 *$ & 1.5 & 33.7 & 18.6 & 9.3 & 38.4 & 1.87 & 1.7 \\
\hline Sourcing for farm inputs & 81.4 & 5.8 & 3.5 & 9.3 & $3.41 *$ & 1.3 & 52.3 & 5.8 & 3.5 & 38.4 & 2.28 & 1.9 \\
\hline Spraying against pests \& diseases & 68.6 & 9.3 & 12.8 & 9.3 & $3.06^{*}$ & 1.5 & 27.9 & 11.6 & 16.3 & 44.2 & 1.60 & 1.7 \\
\hline Harvesting of ripped cocoa pods & 69.8 & 14.0 & 7.0 & 9.3 & $3.14 *$ & 1.4 & 27.9 & 17.4 & 7.0 & 47.7 & 1.63 & 1.8 \\
\hline Breaking of cocoa pods & 68.6 & 15.1 & 7.0 & 9.3 & $3.12 *$ & 1.4 & 27.9 & 17.4 & 10.5 & 44.2 & 1.66 & 1.7 \\
\hline Scooping of cocoa seeds from pods & 68.8 & 12.8 & 9.3 & 9.3 & $3.09 *$ & 1.4 & 12.2 & 30.3 & 12.8 & 44.2 & 1.48 & 1.5 \\
\hline Fermentation and checking of cocoa beans & 75.6 & 11.6 & 3.5 & 9.3 & $3.31 *$ & 1.3 & 31.4 & 30.2 & 0 & 38.4 & 2.07 & 1.7 \\
\hline Transportation of cocoa beans within farm & 68.6 & 11.7 & 10.5 & 9.3 & $3.09 *$ & 1.4 & 12.8 & 32.6 & 10.5 & 44.2 & 1.43 & 1.5 \\
\hline Sun-drying and removal of bad cocoa beans & 75.6 & 11.6 & 3.5 & 9.3 & $3.35 *$ & 1.3 & 37.2 & 20.9 & 3.5 & 38.4 & 2.15 & 1.8 \\
\hline
\end{tabular}




\begin{tabular}{|c|c|c|c|c|c|c|c|c|c|c|c|c|}
\hline \multirow{2}{*}{ Cocoa Production Activities } & \multicolumn{7}{|c|}{ Male $<50$ Years $(\%), N=68$} & \multicolumn{5}{|c|}{ Male $>50$ Years $(\%), N=68$} \\
\hline & AI & MTI & ATI & NI & MS & SD & AI & MTI & ATI & NI & MS & SD \\
\hline Marketing of cocoa & 81.4 & 68.6 & 3.5 & 9.3 & $3.42 *$ & 1.3 & 54.7 & 7.0 & 0 & 38.4 & $2.50^{*}$ & 1.9 \\
\hline Sourcing fund for farm operations & 81.4 & 5.8 & 3.5 & 9.3 & $3.41 *$ & 1.3 & 54.7 & 7.0 & 0 & 38.4 & $2.50^{*}$ & 1.9 \\
\hline Hiring labourers and determining wages & 81.4 & 5.8 & 3.5 & 9.3 & $3.41^{*}$ & 1.3 & 54.7 & 7.0 & 0 & 38.4 & 2.40 & 1.9 \\
\hline Expansion of household cocoa farm & 68.6 & 12.8 & 3.5 & 15.1 & $3.10^{*}$ & 1.5 & 25.6 & 33.7 & 0 & 40.7 & 1.97 & 1.7 \\
\hline Replacement of dead cocoa stands & 68.6 & 12.8 & 3.5 & 15.1 & $3.07 *$ & 1.5 & 25.6 & 36.1 & 0 & 38.4 & 1.98 & 1.7 \\
\hline
\end{tabular}

Source: Field Survey, $2015 *$ High Level of Involvement.

Key: Always Involved - AI, Most Times Involved - MTI, At Times Involved - ATI, Never Involved - NI.

Table 3. Changing Pattern of Female Involvement in Cocoa Production as affected by Age.

\begin{tabular}{|c|c|c|c|c|c|c|c|c|c|c|c|c|}
\hline \multirow{2}{*}{ Cocoa Production Activities } & \multicolumn{6}{|c|}{ Female $<50$ Years $(\%), N=49$} & \multicolumn{6}{|c|}{ Female $>50$ Years $(\%), N=49$} \\
\hline & AI & MTI & ATI & NI & MS & SD & AI & MTI & ATI & NI & MS & SD \\
\hline Choosing location for farm site & 12.9 & 16.2 & 29.0 & 41.9 & 2.2 & 1.4 & 0 & 9.7 & 29.0 & 61.3 & 1.2 & 0.8 \\
\hline Bush clearing and land preparation & 0 & 16.1 & 74.2 & 9.7 & 1.9 & 0.6 & 0 & 9.7 & 29.0 & 61.3 & 1.1 & 0.8 \\
\hline Securing planting materials & 19.4 & 9.7 & 29.0 & 41.9 & 2.3 & 1.5 & 0 & 9.7 & 29.0 & 61.3 & 1.2 & 0.8 \\
\hline Raising cocoa seedlings nursery & 22.6 & 6.5 & 61.3 & 9.7 & $2.6^{*}$ & 1.4 & 0 & 9.7 & 29.0 & 61.3 & 1.8 & 0.9 \\
\hline Planting of cocoa seedlings & 16.0 & 13.0 & 61.3 & 9.7 & $2.6^{*}$ & 1.3 & 0 & 9.7 & 29.0 & 61.3 & 1.8 & 0.9 \\
\hline Sourcing for farm inputs & 29.0 & 9.7 & 29.0 & 32.3 & 2.7 & 1.7 & 0 & 9.7 & 29.0 & 61.3 & 1.2 & 0.8 \\
\hline Weeding and pruning & 0 & 29.1 & 29.0 & 41.9 & 1.9 & 1.0 & 0 & 9.7 & 29.0 & 61.3 & 1.2 & 0.7 \\
\hline Spraying against pests $\&$ diseases & 0 & 58.0 & 32.3 & 9.7 & $2.5^{*}$ & 0.7 & 0 & 38.7 & 0 & 61.3 & 1.8 & 1.0 \\
\hline Harvesting of ripped cocoa pods & 12.9 & 25.8 & 29.0 & 32.3 & $2.5^{*}$ & 1.4 & 0 & 9.7 & 29.0 & 61.3 & 1.2 & 0.7 \\
\hline Breaking of cocoa pods & 12.9 & 25.8 & 29.0 & 32.3 & $2.5^{*}$ & 1.4 & 0 & 9.7 & 29.0 & 61.3 & 1.2 & 0.8 \\
\hline Scooping of cocoa seeds from pods & 22.6 & 77.4 & 0 & 0 & $3.6^{*}$ & 0.5 & 3.2 & 35.5 & 0 & 61.3 & 1.8 & 1.5 \\
\hline Fermentation and checking of cocoa beans & 22.6 & 48.4 & 29.0 & 0 & $3.6^{*}$ & 1.1 & 3.2 & 6.5 & 29.0 & 61.3 & 1.2 & 0.9 \\
\hline Transportation of cocoa beans within farm & 22.6 & 77.4 & 0 & 0 & $2.9^{*}$ & 0.8 & 3.2 & 35.5 & 0 & 61.3 & 2.0 & 1.1 \\
\hline Sun-drying and removal of bad cocoa beans & 38.7 & 61.3 & 0 & 0 & $3.4^{*}$ & 0.5 & 9.7 & 29.0 & 0 & 61.3 & 1.5 & 1.6 \\
\hline Bagging/storage of dried cocoa beans & 38.7 & 61.3 & 0 & 0 & $3.5^{*}$ & 1.3 & 9.7 & 29.0 & 0 & 61.3 & 1.0 & 1.4 \\
\hline Marketing of cocoa & 32.3 & 6.5 & 29.0 & 32.3 & $2.8^{*}$ & 1.7 & 3.2 & 6.5 & 29.0 & 61.3 & 1.6 & 1.0 \\
\hline Sourcing fund for farm operations & 29.0 & 9.7 & 29.0 & 32.3 & $2.7^{*}$ & 1.7 & 3.2 & 6.5 & 29.0 & 61.3 & 2.0 & 0.8 \\
\hline Hiring labourers and determining wages & 48.4 & 9.7 & 9.7 & 32.3 & $3.3^{*}$ & 1.8 & 29.0 & 9.7 & 0 & 61.3 & 1.6 & 1.8 \\
\hline Expansion of household cocoa farm & 12.9 & 25.9 & 29.0 & 32.3 & 2.4 & 1.4 & 0 & 9.7 & 29.0 & 61.3 & 1.2 & 0.7 \\
\hline Replacement of dead cocoa stands & 12.9 & 19.4 & 35.5 & 32.3 & 2.4 & 1.4 & 0 & 3.2 & 35.5 & 61.3 & 1.2 & 0.7 \\
\hline
\end{tabular}

Source: Field Survey, $2015 *$ High Level of Involvement.

Key: Always Involved - AI, Most Times Involved - MTI, At Times Involved - ATI, Never Involved - NI.

\subsection{Hypothesis Testing}

$\mathrm{Ho}_{1}$ : There is no significant difference in the pattern of farmers' involvement in cocoa production activities with respect to age.

Table 4 presents the result of the $\mathrm{t}$ - test that compared level of involvement when less than 50 years and when $\geq 50$ years. The result shows that at 0.05 level of significance, level of involvement of respondents when farmers were less than 50 years with a mean score of 2.8 was significantly different from the level of involvement of respondents when they were above 50 years with a mean score of $1.68,(t=4.68$, $\mathrm{p} \leq 0.05)$, therefore the null hypothesis was rejected. This confirms the earlier findings in the study, that as the respondent age, their involvement in cocoa production decreases.

Table 4. Result of the t- test for Level of Involvement when below 50 and above 50 years.

\begin{tabular}{|c|c|c|c|c|c|c|}
\hline Variable & Mean Values & Mean difference & t-value & df & Sig & Remarks \\
\hline $\begin{array}{l}\text { Level of involvement when }<50 \text { years } \\
\text { Level of involvement when } \geq 50 \text { years }\end{array}$ & $\begin{array}{l}2.80 \\
1.68\end{array}$ & 1.16 & 4.68 & 85 & 0.00 & Significant \\
\hline
\end{tabular}

Source: Field survey, 2015.

\section{Conclusion}

In conclusion, there is evidence that men are more involved in cocoa production activities than male. However, involvement decreased with age for both sexes, which implies that involvement in cocoa production activities decreases as age increases. Also, females utilized sharecroppers more than males in cocoa production activities and this explains reason for lower profit for females since the proceeds will have to be shared between the parties involved.

\section{Recommendation}

It is therefore recommended that farmers who are below 50 years of age should be encouraged into cocoa farming so as to increase cocoa output. 


\section{References}

[1] Nigerian Bureau of Statistics/Federal Republic of Nigeria (2019): Nigerian Gross Domestic Product report, Quarter One 2019. Retrieved online 25th October, 2019 from www.nigerianstat.gov.ng.

[2] ICCO, (2018). Production Values. Available from: http://www.icco.org/faq/57.cocoa-production/123. Accessed Oct. 20, 2019.

[3] Shahbandeh, M. (2019): Cocoa Production by country. Retrieved online from www.statistics.com/statistics/263855/cocoa-bean-productionworldwide-by-region/.

[4] Bello, T and Mitchell, M. I. (2018): The Political Economy of Cocoa in Nigeria: A History of Conflict or Cooperation? Africa Today, Spring. 64 (3), 70-91.

[5] Olasupo, F. O. and Aikpokpodion, P. O. (2019): Cacao Genetic Resources Conservation and Utilization for Sustainable Production in Nigeria. [Online First], IntechOpen, DOI: $10.5772 /$ intechopen.82703.

[6] Aikpokpodion, P. O. and Adeogun, S. O. (2019): A Diagnostic Study of Constraints to Achieving Yield Potentials of Cocoa (Theobroma cacao L.) Varieties and Farm Productivity in Nigeria. Journal of Agricultural Science, 3 (4); 68-76.

[7] Omotayo, A. M. (2010): The Nigerian Farmer and the Elusive Crown, University of Agriculture Abeokuta, Nigeria. 30th Inaugural Lecture.

[8] Hernandez-Deck, M. (2001): Older Farmers: Factors Affecting their Health and Safety. Retrieved Nov. 12, 2012 from: http://www.cdc.gov/nasd/docs/d001701d001800/d0076.

[9] Oboh, V. and Sani, R. M. (2009). The Role of Radio on Campaign against the Spread of HIV/AIDS among Farmers in Markudi, Nigeria. Journal of Social Sciences, 19 (3): 179-184.

[10] Gorman, M. (1999): Development and the Rights of Older People. In: Randel J, et al., eds. The Ageing and Development Report: Poverty, Independence and the World's Older People. London, Earthscan Publications Ltd. pages 3-21.

[11] Hauser, L. T., Van Der Sluis, T. and Giezen, M. (2016). The Role of farm Management Characteristics in Understanding the Spatial Distribution of Landscape Elements: A Case Study in the Netherlands, Rural Landscape; Society, Environment, History, 3 (1). 7: DOI: http://doi.org/10.16993/rl.14.
[12] Fasina, O. O. and Ayodele, O. V. (2018). Gender Analysis of Labour Use among Farmers in Cocoa Production Activities in Ekiti State, Nigeria. Journal of Agriculture and Food Environment. 5 (3): 48-57.

[13] Onumah, J. A., Williams, P. A., Quaye, W. and Akuffobea, M. (2014): Smallholder Cocoa Farmers Access to On/Off-Farm Support Services and its Contribution to Output in Eastern Region of Ghana. Asian Journal of Agriculture and Rural Development, 4 (10): 484-495.

[14] Aidoo, R. and Fromm, I. (2015). Willingness to Adopt Certific ations and Sustainable Production Methods among SmallScale Cocoa Farmers in the Ashanti Region of Ghana. Journal of Sustainable Development; 8 (1), 33. URL. http//dx.doi.org/10.5539/jsd.v8n1p33.

[15] Ayodele, O. V., Fasina, O. O. and Awoyemi, A. A. (2016): Gender Analysis of Farmers' Access to Production Resources in Ekiti State, Nigeria. Journal of Applied Tropical Agriculture. 21 (3): 131-137.

[16] Ademola, A. O. (2016). Livelihood outcomes of beneficiaries of university-based agricultural extension system in southwestern Nigeria. Unpublished PhD thesis, Department of Agricultural Extension and Rural Development, University of Ibadan.

[17] Nkamleu, G. B., Nyemeck J. and Gockowski, J. (2010). Technology Gap and Efficiency in Cocoa Production in West and Central Africa: Implications for Cocoa Sector Development, Working Papers Series No. 104, African Development Bank, Tunisia.

[18] Alston, M. (2000): Breaking through the Grass Ceiling: Women, Power and Leadership in Agricultural Organizations Harwood Academic Publishers, The Netherlands.

[19] Enete A. A. and Amusa T. A. (2010): Contribution of Men and Women to Farming Decisions in Cocoa based Agroforestry Households of Ekiti State, Nigeria. TROPICULTURA, 28, 2, 77-83.

[20] Adeogun, S. O., J. E. Olawoye J. E., and Akinbile L. A. (2010): Information Sources to Cocoa Farmers on Cocoa Rehabilitation Techniques (CRTs) in Selected States of Nigeria Journal Media and Communication Studies 2 (1) 009015 .

[21] Wessel, M. and Quist-Wessel, P. M. F (2015). Cocoa Production in west Africa, a review and analysis of recent developments. NJAS - Wageningen Journal of Life sciences. Vol. 74-75. Pg. 1-7. 